\title{
Binding of Fentanyl and Pethidine to Muscarinic Receptors in Rat Brain
}

\author{
Olav Hustveit \\ Department of Pharmacology, University of Oslo, Oslo, Norway \\ Received July 13, 1993 Accepted September 29, 1993
}

\begin{abstract}
Symptoms similar to the central anticholinergic syndrome are often seen after high dose fentanyl anesthesia. Therefore, the binding of fentanyl, alfentanil, pethidine and morphine to opioid and muscarinic receptors was investigated in rat brain homogenate with $\left[{ }^{3} \mathrm{H}\right]$ naloxone and $\left[{ }^{3} \mathrm{H}\right] \mathrm{QNB}$ as the radioligands, respectively. Both pethidine and fentanyl inhibited $\left[{ }^{3} \mathrm{H}\right] \mathrm{QNB}$ binding with $\mathrm{K}_{\mathrm{i}}$ values in the micromolar range. Alfentanil and morphine had no affinity for muscarinic receptors. The ratio of the $\mathbf{K}_{\mathrm{i}}$ values for muscarinic receptors versus opioid receptors was 2.5 for pethidine and 88 for fentanyl. It is concluded that binding of fentanyl to muscarinic receptors is likely to occur during high-dose fentanyl anesthesia.
\end{abstract}

Keywords: Fentanyl, Muscarinic receptor, Pethidine

High doses of the synthetic opiate fentanyl (50-150 $\mu \mathrm{g} / \mathrm{kg}$ ) produce anesthesia with very good hemodynamic stability and has therefore been used extensively in cardiac surgery. The favorable effects during the peroperative period have been discussed in several publications $(1,2)$, but $I$ have found no articles discussing the postoperative side effects. The side effects include confusion, vigorous shivering, sudden purposeless movements and some times a disturbing rise in heart rate and blood pressure. The symptoms appear similar to the central anticholinergic syndrome (3). The clinical observations suggest that fentanyl may have anticholinergic properties. A prerequisite for a central anticholinergic effect of fentanyl is binding to muscarinic receptors in the brain. The aim of this work was to determine the affinity of fentanyl and some commonly used opiates for opioid and muscarinic receptors in rat brain homogenate to evaluate whether binding of fentanyl to muscarinic receptors is likely to occur during high-dose anesthesia.

Male Wistar rats weighing about $300 \mathrm{~g}$ were anesthetized with ether and decapitated. The brain (minus cerebellum and medulla oblongata) was rapidly removed and homogenized in $15 \mathrm{ml}$ ice-cold $50 \mathrm{mM}$ Tris- $\mathrm{HCl}(\mathrm{pH} 7.4)$ in a Potter-Elvehjem homogenizer. The homogenate was centrifuged at $49,000 \times \mathrm{g}$ for $15 \mathrm{~min}$, resuspended in $20 \mathrm{ml}$ buffer per brain and stored at $-80^{\circ} \mathrm{C}$ until use. Before use, the homogenate was thawed and gently rehomogenized by hand in a Potter-Elvehjem homogenizer. Homogenate aliquots $(0.1 \mathrm{ml})$ were incubated with la- beled and unlabeled ligands in a final volume of $0.4 \mathrm{ml}$. The final protein concentration was approximately 1.4 $\mathrm{mg} / \mathrm{ml}$. Binding to muscarinic receptors was tested using 1-quinuclidinyl[phenyl-4(n)-[ $\left.{ }^{3} \mathrm{H}\right]$ benzilate $\left({ }^{3} \mathrm{H}\right] \mathrm{QNB}, 42$ $\mathrm{Ci} / \mathrm{mmol}$; Amersham, UK) in a final concentration of 1 $\mathrm{nM}$. Nonspecific binding was defined as the binding in the presence of $1 \mu \mathrm{M}$ atropine. Binding to opioid receptors was tested using $\left[{ }^{3} \mathrm{H}\right]$ naloxone $(61 \mathrm{Ci} / \mathrm{mmol}$, Amersham) in a final concentration of $2 \mathrm{nM}$. Nonspecific binding was measured in the presence of $10 \mu \mathrm{M}$ naloxone or $10 \mu \mathrm{M}$ levorphanol. Saturation studies were performed for $\left[{ }^{3} \mathrm{H}\right]$ naloxone with 18 concentrations between 0.2 and $100 \mathrm{nM}$ and for $\left[{ }^{3} \mathrm{H}\right] \mathrm{QNB}$ with 9 concentrations between 0.2 and $5 \mathrm{nM}$. Samples were incubated at $30^{\circ} \mathrm{C}$ for $30 \mathrm{~min}$ for $\left[{ }^{3} \mathrm{H}\right]$ QNB binding and $22^{\circ} \mathrm{C}$ for $20 \mathrm{~min}$ for $\left[{ }^{3} \mathrm{H}\right]$ naloxone binding. After incubation, the samples were rapidly filtered through Whatman $\mathrm{GF} / \mathrm{C}$ glass fiber filters and washed 3 times with $4 \mathrm{ml}$ ice-cold buffer and counted in a Beckman scintillation spectrophotofluorimeter. Specific binding for the radioligands was measured for protein concentrations up to $20 \%$ higher than the concentration used in the saturation and displacement experiments and was found to be linearly dependent on the protein concentration. Binding parameters were calculated by the computer program LIGAND (4) modified for microcomputers by G.A. McPherson (Elsevier-BIOSOFT; Cambridge, UK).

The binding data obtained from saturation assays with $\left[{ }^{3} \mathrm{H}\right] \mathrm{QNB}$ fitted only with a one site model. The calculated 


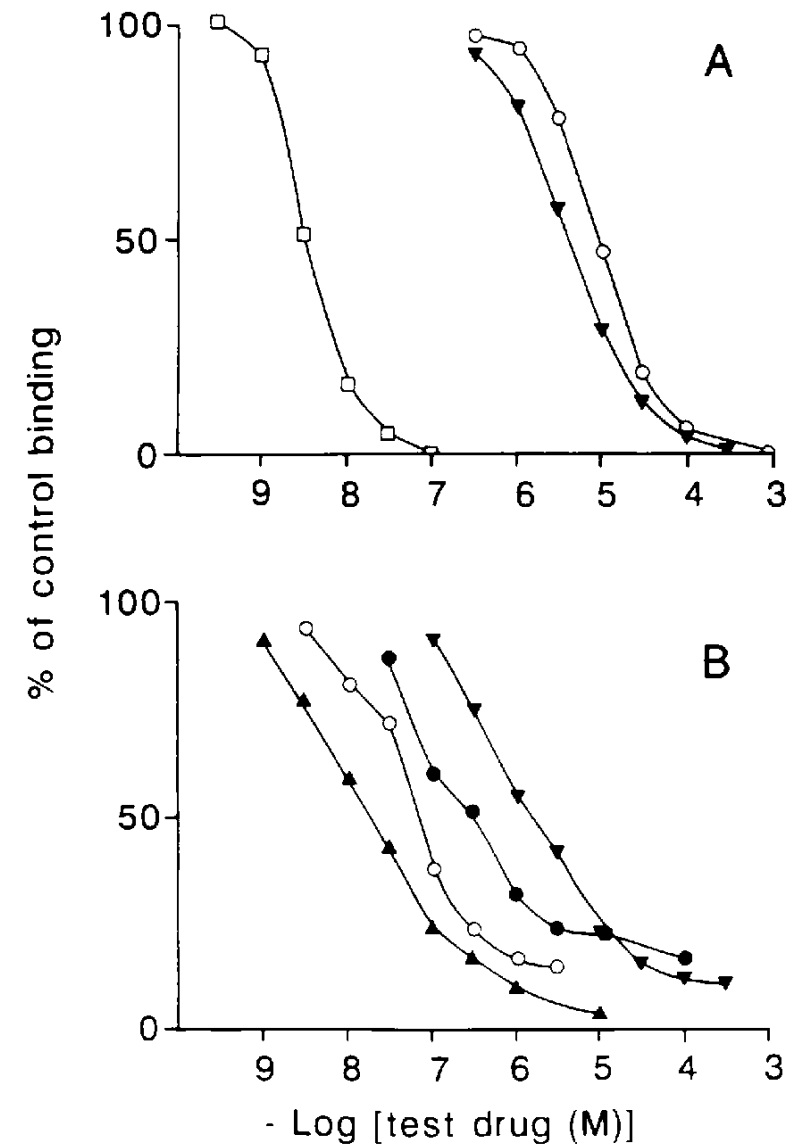

Fig. 1. Inhibition of binding of $1 \mathrm{nM}\left[{ }^{3} \mathrm{H}\right] \mathrm{QNB}$ (A) and $2 \mathrm{nM}$ $\left[{ }^{3} \mathrm{H}\right]$ naloxone (B) to rat brain membranes. Symbols: atropine $(\square)$, pethidine $(\boldsymbol{\nabla})$, fentanyl $(\bigcirc)$, morphine $(\boldsymbol{A})$ and alfentanil $(\boldsymbol{O})$.

dissociation constant $\left(\mathrm{K}_{\mathrm{d}}\right)$ was $0.61 \pm 0.04$ (S.E.M.) $\mathrm{nM}$ and the receptor density $\left(\mathrm{B}_{\mathrm{max}}\right)$ was $1.8 \mathrm{pmol} / \mathrm{mg}$ protein. Also the inhibition curves (Fig. 1A) fitted only with a one site model. Fentanyl and pethidine inhibited $\left[{ }^{3} \mathrm{H}\right] \mathrm{QNB}$ to the same extent as atropine. The results obtained from the inhibition assays are presented as calculated inhibition constants $\left(K_{i}\right.$ values) in Table 1. Atropine inhibited $\left[{ }^{3} \mathrm{H}\right] \mathrm{QNB}$ in the nanomolar concentration range. Morphine, alfentanil, naloxone and diazepam had no affinity for muscarinic receptors. Fentanyl and pethidine, however, inhibited $\left[{ }^{3} \mathrm{H}\right] \mathrm{QNB}$ binding, both with $\mathrm{K}_{\mathrm{i}}$ values in the micromolar range. The affinity of fentanyl for muscarinic receptors was only slightly ( 0.6 times) lower than that of pethidine.

The data obtained from saturation studies with $\left[{ }^{3} \mathrm{H}\right]-$ naloxone fitted best with a two site model with one high affinity and one low affinity site. For the high affinity site, a $\mathrm{K}_{\mathrm{d}}$ value of $0.9 \pm 0.2$ (S.E.M.) $\mathrm{nM}$ and a receptor density of $40 \mathrm{fmol} / \mathrm{mg}$ protein was found. The non-specific binding found when the radioactive ligand was displaced with $10 \mu \mathrm{M}$ levorphanol was about $30 \%$ higher than that
Table 1. Inhibition of $\left[{ }^{3} \mathrm{H}\right] \mathrm{QNB}$ (muscarinic receptors) and $\left[{ }^{3} \mathrm{H}\right]$ naloxone (opioid mu-receptor) binding to rat brain membranes

\begin{tabular}{lcc}
\hline & \multicolumn{2}{c}{$\mathrm{K}_{\mathrm{i}}(\mathrm{nM})$} \\
\cline { 2 - 3 } & {$\left[{ }^{3} \mathrm{H}\right]$ naloxone } & {$\left[{ }^{3} \mathrm{H}\right] \mathrm{QNB}$} \\
\hline Morphine & $3.5 \pm 0.6$ & $\mathrm{nb}$ \\
Pethidine & $263 \pm 52$ & $670 \pm 36$ \\
Fentanyl & $12 \pm 1.8$ & $1060 \pm 214$ \\
Alfentanil & $39 \pm 7.2$ & $\mathrm{nb}$ \\
Atropine & $\mathrm{nb}$ & $0.61 \pm 0.03$ \\
Diazepam & $\mathrm{nb}$ & $\mathrm{nb}$ \\
\hline
\end{tabular}

Each drug was tested in three separate experiments performed in triplicate. The $K_{i}$ values with S.E.M. were estimated with the computer program Ligand. $n b=$ no binding detected.

defined with $10 \mu \mathrm{M}$ naloxone. The computer program estimated a non-specific binding which was very close to the one defined with naloxone, and therefore this was used. The choice of naloxone or levorphanol to define nonspecific binding had a negligible effect on the $K_{d}$ and $B_{\max }$ for the high affinity site. Also the data obtained from inhibition assays for $\left[{ }^{3} \mathrm{H}\right]$ naloxone binding (Fig. 1B) fitted best with a two site model. The results for the high affinity (mu-receptor) site are presented in Table 1. Morphine had the highest affinity for mu-receptors, followed by fentanyl, alfentanil and pethidine.

The present study shows for the first time that fentanyl and pethidine bind to muscarinic receptors in the brain. Although all five subtypes of muscarinic receptors that have been cloned (5) are believed to be present in the brain, the computer analyses of the binding isotherms fitted only with a one site model. Also, fentanyl and pethidine inhibited $\left[{ }^{3} \mathrm{H}\right] \mathrm{QNB}$ binding to the same extent as atropine. The findings indicate that the two drugs bind to all the subtypes of muscarinic receptors present in the brain with no substantial difference in affinity for the different subtypes. This is in agreement with previous findings for atropine and QNB (6). The saturation and inhibition curves for $\left[{ }^{3} \mathrm{H}\right]$ naloxone fitted best with a two site model. The binding parameters for the high affinity site is consistent with an opioid mu-receptor. The low affinity site probably represent kappa/delta-receptors. The affinity of fentanyl for muscarinic receptors is low compared to opioid receptors $(1: 88)$. For pethidine, the ratio is smaller $(1: 2.5)$. Neither morphine nor alfentanil inhibited $\left[{ }^{3} \mathrm{H}\right] \mathrm{QNB}$ binding. The receptor densities and the affinities of the opiates for opioid receptors and atropine and QNB for muscarinic receptors agree well with previously reported results.

In order for fentanyl and pethidine to produce the central anticholinergic syndrome, they must be antagonists on muscarinic receptors. It has been shown that the two 
drugs are antagonists on the M3-subtype (7), but it is not known whether they are agonists or antagonists on the other subtypes, although the latter is more likely. It is not known which of the subtypes are responsible for the central anticholinergic syndrome.

The side effects seen after high-dose fentanyl anesthesia are dose-dependent. In our hands, they were almost invariably seen when the highest doses were used, while they were less frequently seen with lower doses. For this reason, if binding of fentanyl to muscarinic receptors is the cause of the side effects, the affinity of fentanyl must be considerably lower for muscarinic than for opioid receptors. It has been shown that the concentration of fentanyl during and after high-dose anesthesia is very high $(2,8)$ compared to the analgesic doses $(9)$. In these investigations, fentanyl was given as a single bolus injection or a bolus injection combined with a continuous infusion. The concentration during recovery from anesthesia will be substantially higher when additional doses are given towards the end of the operation. Thus, although the affinity of fentanyl for muscarinic receptors is low, the serum concentrations may reach such high levels that binding to muscarinic receptors in the brain during high-dose anesthesia is very likely to occur. Whether this putative binding can explain the side effects seen during recovery from anesthesia can not be assessed with in vitro studies alone.

Pethidine was originally synthesized as an anticholinergic drug but turned out to be a strong analgesic agent (10). Although it has been known for decades that pethidine has anticholinergic properties, I have not been able to find any binding data for pethidine on cholinergic receptors. The present study confirms that pethidine binds to both muscarinic and opioid receptors with almost the same affinity. This is in agreement with the clinical observation that analgesic doses of pethidine may cause mild peripheral anticholinergic effects $(10,11)$. Such doses may be too low for substantial binding to muscarinic receptors in the brain. During treatment of chronic pain, tolerance develops, and higher doses of pethidine are needed. In such cases, symptoms resembling the central anticholinergic syndrome are reported (12).

In conclusion, the present study shows that fentanyl and pethidine bind to muscarinic receptors in rat brain homogenate. Binding of fentanyl to muscarinic receptors in the brain is very likely to occur during high-dose anesthesia. Further investigations are needed to determine if binding to muscarinic receptors is the cause of the side effects seen after high-dose fentanyl anesthesia.

\section{REFERENCES}

1 Stanley, T.H. and Webster, L.R.: Anesthetic requirements and cardiovascular effects of fentanyl-oxygen and fentanyl-diazepam-oxygen anesthesia in man. Anesth. Analg. 57, 411-416 (1978)

2 Wynands, J.E., Townsend, G.E., Wong, P., Whalley, D.G., Sirikant, C.B. and Patel, Y.C.: Blood pressure response and plasma fentanyl concentrations during high- and very high-dose fentanyl anesthesia for coronary artery surgery. Anesth. Analg. 62, $661-665$ (1983)

3 Longo, V.G.: Behavioral and electroencephalographic effects of atropine and related compounds. Pharmacol. Rev. 18, 965-996 (1966)

4 Munson, P.J. and Rodbard, D.: Ligand: A versatile computerized approach for characterization of ligand-binding systems. Anal. Biochem. 107, 220-239 (1980)

5 Bonner, T.I.: New subtypes of muscarinic acetylcholine receptors. Trends Pharmacol. Sci. Supp. 4, 11-15 (1989)

6 Bolden, C., Cusack, B. and Richelson, E.: Antagonism by antimuscarinic and neuroleptic compounds at the five cloned human muscarinic receptors expressed in Chinese hamster ovary cells. J. Pharmacol. Exp. Ther. 260, 576-580 (1992)

7 Hustveit, O. and Setekleiv, J.: Fentanyl and pethidine are antagonists on muscarinic receptors in guinea-pig ileum. Acta Anaesth. Scand. 37, 541-544 (1993)

8 Schleimer, R., Benjamini, E. and Eisele, J.: Pharmacokinetics of fentanyl as determined by radioimmunoassay. Clin. Pharmacol. Ther. 23, 188- 194 (1978)

9 Duthie, D.J.R., McLaren, A.D. and Nimmo, W.S.: Pharmacokinetics of fentanyl during constant rate i.v, infusion for the relief of pain after surgery. Br. J. Anaesth. 58, 950-956 (1986)

10 Schauman, O.: Über eine neue Klasse von Verbindungen mit spasmolytischer und zentral analgetischer Wirksamkeit unter besonderer Berücksichtigung des 1-Methyl-4-phenyl-piperidin-4carbonsäure-äthylesters (Dolantin). Arch. Exp. Pathol. Pharmacol. 196, 109-136 (1940) (in German)

11 Batterman, R.C. and Himmelsbach, C.K.: Demerol-a new synthetic analgesic. J. Am. Med. Assoc. 122, 222-226 (1943)

12 Kaiko, R.F., Foley, K.M., Grabinski, P.Y., Heidrich, G., Rogers, A.G., Inturrisi, C.E. and Reidenberg, M.M.: Central nervous system exitatory effects of meperidine in cancer patients. Ann. Neurol. 13, 180-185 (1983) 